\title{
The Variability of the Planktonic Algae Biomass and Their Species Structure in the Ponds of the Park and Palace Complex in Żywiec
}

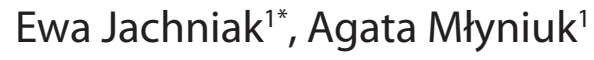 \\ 1 Institute of Environmental Protection and Engineering, University of Bielsko-Biala, Poland \\ * Corresponding author's e-mail: ejachniak@ath.bielsko.pl
}

\begin{abstract}
The aim of this research was the analysis of the species composition and planktonic algae biomass in the ponds of Habsburg Park in Żywiec. So far, the urban park ponds have been rarely studied (especially in Poland) in this respect. The analyses of the park ponds water in Żywiec were conducted during the vegetation season in 2016, in monthly intervals. The phytoplankton biomass was calculated by comparing the shape of algae to geometrical figures and based on the chlorophyll a concentrations. The chlorophyll a concentrations and values of the planktonic algae biomass remained at a low level. The species composition showed the dominance of diatoms (i.a. Achnanthes lanceolate (Brébisson ex Kützing) Grun. in Cl. \& Grun., Encyonema sp. (Kützing) Krammer). The highest values of the planktonic algae biomass were observed in the summer season. The ponds in the Habsburgs Park in Żywiec have great aesthetic and recreational values and therefore more frequent monitoring is necessary.
\end{abstract}

Keywords: planktonic algae biomass, urban park ponds

\section{INTRODUCTION}

Planktonic algae belong to microscopic organisms, which live in the water column. They occur in lakes, dam reservoirs, ponds (fish, town, park), forest and field ponds. They mostly belong to autotrophic organisms, but there are also heterotrophic and mixotrophic organisms among them (the latter feed on both autotrophic and heterotrophic organisms) [Bucka, Wilk-Woźniak 2007; Danielsen 2010; Fernández et al. 2015; Nishino et al. 2015; Bora et al. 2016; Goswami et al. 2017].

In the opinion of Reynolds (2000), microscopic algae are very good bioindicators of water environment, because they well reflect the trophic state of water ecosystems. Certain species can develop only in oligotrophic water, while other species can develop in eutrophic water [Reynolds et al. 1998; Rakowska et al. 2005; Peretyatko et al. 2007; Danielsen 2010; Fernández et al. 2015; Bora et al. 2017; Salmaso et al. 2017].

Planktonic algae showing the definite trophic state of the dam reservoirs water must be stenobionts,i.e. they must develop in closely defined environment conditions. Only these organisms constitute good bioindicators of the characteristic trophy level and the degree of water pollution [Kawecka, Eloranta 1994; Bucka, WilkWoźniak 2007].

The research on the species and quantitative structure of the planktonic algae in park ponds has rarely been conducted so far. The dam reservoirs [Starmach, Mazurkiewicz-Boroń 2000; Wilk-Woźniak, Ligęza 2003; Mukhutdinov, Butakova 2012; ZhengJian et al. 2013; Fernández et al. 2015] and lakes [Bubak, Bogaczewicz-Adamczak 2005; Ptacnik et al. 2009; Danielsen 2010; Nishino et al. 2015] are most often described in this respect), because algae are good indicators of the changing trophic conditions and it has economic significance for these reservoirs. These organisms have been abundantly presented in the articles which concern breeding fish ponds, due to their significance in the fishing industry [Burchardt et al. 2006; Bucka, Wilk-Woźniak 2007; Wilk-Woźniak et al. 2011], forest ponds [Chomutowska, Krzyściak-Kosińska 2015] and 
also ponds of peatlands [Szczurowska 2003; Wołowski 2011].

Thus far, small water reservoirs located in urban parks have rarely been studied (especially in Poland) in this respect [Messyasz, Jurgońska 2003]. These parks are often used as recreational areas; therefore, the purity of their ponds water is important. The research on algae was conducted i.a. in the ponds of Solacki Park in Poznań [Messyasz, Jurgońska 2003], also in the ponds of botanical garden of the Jagiellonian University in Krakow [Wołowski, Kowalska 2009] and in other urban ponds [Peretyatko et al. 2007; Dmitrov et al. 2011; Goswami et al. 2017]. In these small reservoirs, zooplankton and bottom macrofauna [Ejsmont-Karabin, Kuczynska-Kippen 2001; WilkWoźniak et al. 2011; Saha et al. 2017], as well as water plants [Gąbka, Dolata 2010; Bubíková, Hrivnák 2018] are described more often.

The aim of this research was the analysis of the species composition and phytoplankton biomass in the ponds of Habsburg Park in Żywiec.

\section{MATERIALS AND METHODS}

\section{Study area}

The research of the planktonic algae and chlorophyll $a$ concentrations was conducted in the water of the ponds located in the Habsburg Park in Żywiec.

In the area of Habsburg Park in Żywiec, there is an Old Habsburg Castle (now there is the Municipal Museum in Żywiec) and a new Habsburg palace. Żywiec is a town, which is located in the southern part of the Silesian Voivodship, in southern Poland, at the confluence of two rivers: Soła and Koszarawa. It is an economically developed city with well-known global companies: Grupa Żywiec S.A. (beer production) and ŻYWIEC ZDRÓJ S.A. (production of Żywiec-Zdrój water). It is also a great base for mountain tourism, because Żywiec is located at the foot of the Western Beskids. Due to the proximity of the recreational Tresna reservoir, it is also visited by the people who enjoy sunbathing and sailing. The city is surrounded by the Western Beskid mountains (Silesian Beskid from the west, Little Beskid from the north, Makowski Beskid from the east and Żywiecki Beskid from the south [Słomka 2007; Poviat Eldership in Żywiec 2013].
The Habsburg palace and castle are surrounded by the park, which has an area of over 28 ha (including 0.3 ha of water). It belongs to one of the larger urban park complexes in Europe. It was repeatedly rebuilt, i.a. created on the Italian pattern and then on the English style. The park ponds come from the late 18th century and they are a habitat for ducks and swans. In the western part of the park there is an island with the so-called Chinese house (with a cafe), which is surrounded by park ponds. There are numerous walking paths in the park. This park is a valuable natural place which is also attractive for tourists, and therefore visited by numerous people [Żywotko 2000; Miodoński 2012].

\section{Research methodology}

The analyses of the park ponds water in Żywiec were conducted during the vegetation season, from May to October 2016 year, in monthly intervals. The ponds are supplied by the Soła River, which flows close to the park [Poviat Eldership in Żywiec 2013]. The water samples for the research were taken from two research points. These points were located in the north-west part of the park (the first research point-P1) and in the south-east part of the park (the second research point - P2). The first research point was situated in a sunny place, while the second research point was located in a shadier place (Fig. 1)

The research of water samples were conducted in the laboratory of Institute of Environmental Protection and Engineering in University of Bielsko-Biala. The following analyses were carried out: determination of the species structure and phytoplankton biomass. In addition, the water temperature was determined. The temperature of water was measured during sampling using a thermometer.

The algae analyses were performed by using the Nikon Eclipse 200 light microscope. A chamber with a height of $0.4 \mathrm{~mm}$ and a diameter of $20 \mathrm{~mm}$ was used. The algae were counted in 17 fields of view, in three replications. The concentration of the each specimen was calculated according to Lund et al. [1958]. The phytoplankton biomass (in wet mass) was calculated for biovolume by comparing the shape of algae to geometrical figures (direct method) [Rott 1981] and based on the concentrations of chlorophyll $a$ (indirect method). the following converter was used for evaluation of the phytoplankton biomass 


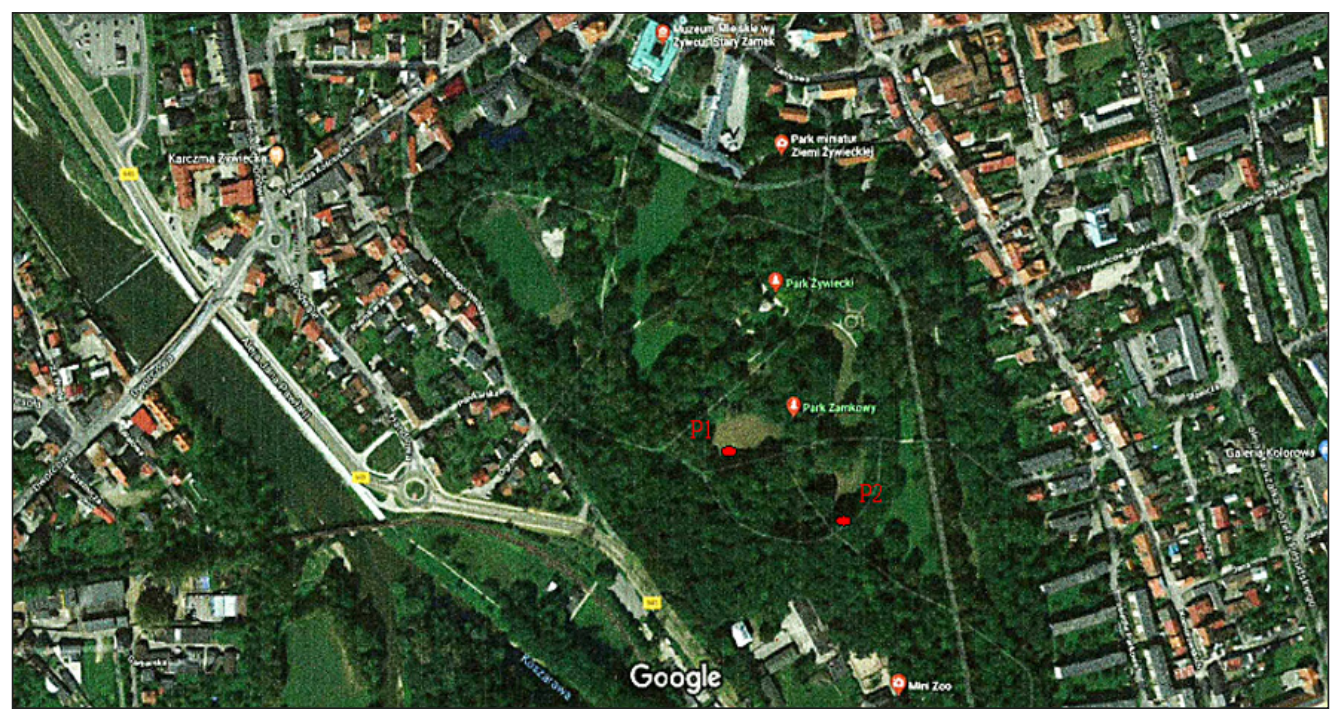

Figure 1. Location of research points

(involving comparison of the shape of algae to geometrical figures) [Rott 1981]:

$$
1 \mu \mathrm{m}^{3}=1 / 1 \cdot 10^{9} \mathrm{~mm}^{3}=1 / 1 \cdot 10^{9} \mathrm{mg}
$$

The following keys were used for the identification of phytoplankton species: Sieminska [1964], Starmach [1989], Hindak [1996], Cox [1999], Picińska-Fałtynowicz, Błachuta [2012]. The species identification was consulted with specialists.

Determination of the chlorophyll $a$ concentration was conducted with the spectrophotometric method in accordance with Polish Standard $\mathrm{PN}-86$ / C -05560.02 .

In addition, the trophic level of the ponds water was defined. It was determined on the basis of the species composition (indicating taxa were used, taking into account the specialist literature [Reynolds 2000; Bucka, Wilk-Woźniak 2007; Ligęza, Wilk-Woźniak 2011; Falasco et al. 2012; Picińska-Fałtynowicz, Błachuta 2012; Järvinen et al. 2013; Kozak et al. 2017; Salmaso et al. 2017] and phytoplankton biomass, according to the Heinonen classification [Heinonen 1980] and the OECD [1982] classification (which includes the concentrations of the chlorophyll $a$ ), which was given by Dojlido [1995] (Table 1).

\section{RESULTS}

\section{The analysis of the air and water temperature}

The temperature of the pond water during the whole the study period was rather high (Table 2), which is characteristic of stagnant and very slow flowing water. Although the pond water is supplied with river water, it flows very slowly in the park area, so the pond water heats up quickly. In addition, the water of the shallow water reservoirs, i.a. ponds water is subject to rapid heating and rapid cooling, because the variability of water temperature depends on the changes in air temperature [Kajak 2001]. These conditions favor the development of the planktonic algae.

\section{The analysis of the phytoplankton biomass variability (determined by both methods: indirect and direct)}

The results of the research showed that the chlorophyll $a$ concentrations at the first research point oscillated between $0.89 \mu \mathrm{g} \cdot \mathrm{dm}^{-3}$ and $3.56 \mu \mathrm{g} \cdot \mathrm{dm}^{-3}$ (Fig. 2). The lowest value was found in October, while the highest value was recorded in September.

Table 1. The boundary values, which are including the biomass of the planktonic algae and the concentrations of the chlorophyll a for particular trophy levels [Heinonen, 1980; OECD, 1982; Dojlido, 1995]

\begin{tabular}{|c|c|c|}
\hline $\begin{array}{c}\text { The trophic type } \\
\text { of water }\end{array}$ & $\begin{array}{c}\text { The ranges of average values the whole } \\
\text { biomass of phytoplankton }\left[\mathrm{mg} \cdot \mathrm{dm}^{-3}\right]\end{array}$ & $\begin{array}{c}\text { The boundary values for concentrations } \\
\text { of the chlorophyll } a\left[\mu \mathrm{g} \cdot \mathrm{dm}^{-3}\right]\end{array}$ \\
\hline Oligotrophy & $0.14-0.68$ & $<2.5$ \\
\hline Mesotrophy & $1.21-1.98$ & $2.5-8$ \\
\hline Eutrophy & $3.45-6.93$ & $8-25$ \\
\hline Hipertrophy & 17.5 & $>25$ \\
\hline
\end{tabular}


At the second research point, the concentrations of this pigment ranged between $0.53 \mu \mathrm{g} \cdot \mathrm{dm}^{-3}$ and $2.67 \mu \mathrm{g} \cdot \mathrm{dm}^{-3}$. The minimum value was recorded in May, and the maximum value was recorded in September (Fig. 2).

Similar seasonal variation of the phytoplankton biomass to chlorophyll $a$ variability was observed; the highest values were also recorded in the summer season. The highest biomass values were recorded at both sites in September $\left(1.89 \mathrm{mg} \cdot \mathrm{dm}^{-3}\right.$ - the research point 1 and $1.69 \mathrm{mg} \cdot \mathrm{dm}^{-3}$ - the research point 2), while the lowest values were found in October at research point $1\left(0.46 \mathrm{mg} \cdot \mathrm{dm}^{-3}\right)$ and in May at research point $2\left(0.59 \mathrm{mg} \cdot \mathrm{dm}^{-3}\right)$ (Fig. 2).

The chlorophyll $a$ concentrations and values of the phytoplankton biomass at the both research points remained low. The highest concentrations occurred in the summer season, which were connected with high air and water temperatures and sunny weather (Table 2). These conditions favored the development of the planktonic algae. The area of the park is a very attractive place for leisure, both for the inhabitants of Żywiec and tourists. The park is frequently visited especially in the summer season, when park alleys and flower carpets attract many tourists. It can cause the flow of the biogenic substances to the park ponds, which are a source of the food for planktonic algae.

\section{The analysis of species composition of the planktonic algae}

Diatoms dominated among the planktonic algae in the analyzed ponds (on both research points), and among them the taxa which prefer the oxygenated water with lower fertility were found, i.a. Achnanthes lanceolata (Brébisson ex Kützing) Grun. in Cl. \& Grun., Encyonema sp. (Kützing) Krammer and Encyonema minutum (Hilse) D.G. Mann [Bubak, Bogaczewicz-Adamczak 2005;
Bucka, Wilk-Woźniak 2007; Keatley et al. 2009; Falasco et al. 2012; Jachniak et al. 2015]. The presence of Chrysophyta, mainly Dinobryon sp. (Ehrenberg) was also found, which can confirm the purity of water, their good oxygenation and low productivity [Forsström et al. 2005; Bucka, Wilk-Woźniak 2007; Ptacnik et al. 2009; Järvinen et al. 2013]. During the research, Cyanobacteriae did not occur either, which usually indicates the eutrophic conditions [Ryding, Rast per WilkWoźniak 2003; Ptacnik et al. 2009; Järvinen et al. 2013]. Periodically, the presence of the species was recorded only during the summer season, which indicated on the increase the trophy level, i.a. green algae: Pediastrum sp. (Meyen) and diatoms: Fragilaria crotonensis Kitt. [Rakowska et al. 2005; Danielsen 2010; Kozak et al. 2017]. Periodically, Euglenophyta appeared as well, which indicated a slight increase of the organic matter pollution [Bucka, Wilk-Woźniak 2007; Wołowski, Kowalska 2009; Rodrigues et al. 2015].

\section{The determination of the water trophic level in park ponds}

The analyzed water had an oligo- /mesotrophic character, with a tendency to mesotrophy in the summer season, at the both research points (Fig. 3).

\section{DISCUSSION}

The research on the ponds within the palace and park complex in Żywiec showed that the highest chlorophyll $a$ concentrations and the values of the planktonic algae biomass occurred in the summer season. It was connected with high air and water temperature and sunny weather in this time. These conditions favored the development of the planktonic algae.

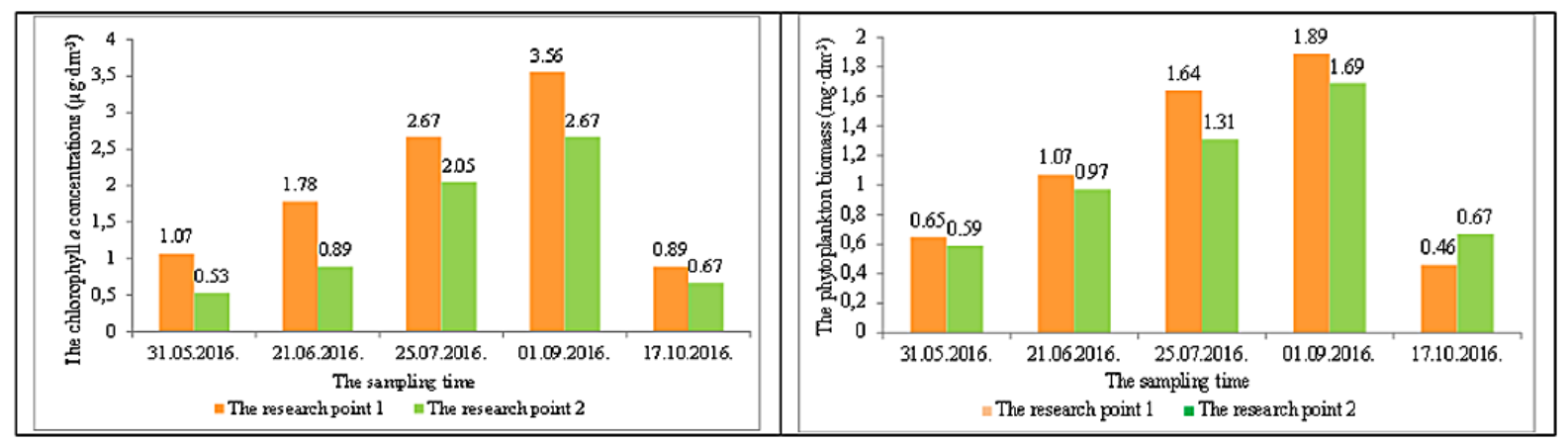

Figure 2. Results of the phytoplankton biomass variability 
Table 1. The boundary values, which are including the biomass of the planktonic algae and the concentrations of the chlorophyll $a$ for particular trophy levels [Heinonen, 1980; OECD, 1982; Dojlido, 1995]

\begin{tabular}{|c|c|c|}
\hline $\begin{array}{c}\text { The trophic type } \\
\text { of water }\end{array}$ & $\begin{array}{c}\text { The ranges of average values the whole } \\
\text { biomass of phytoplankton }\left[\mathrm{mg} \cdot \mathrm{dm}^{-3}\right]\end{array}$ & $\begin{array}{c}\text { The boundary values for concentrations } \\
\text { of the chlorophyll } a\left[\mu \mathrm{g} \cdot \mathrm{dm}^{-3}\right]\end{array}$ \\
\hline Oligotrophy & $0.14-0.68$ & $<2.5$ \\
\hline Mesotrophy & $1.21-1.98$ & $2.5-8$ \\
\hline Eutrophy & $3.45-6.93$ & $8-25$ \\
\hline Hipertrophy & 17.5 & $>25$ \\
\hline
\end{tabular}

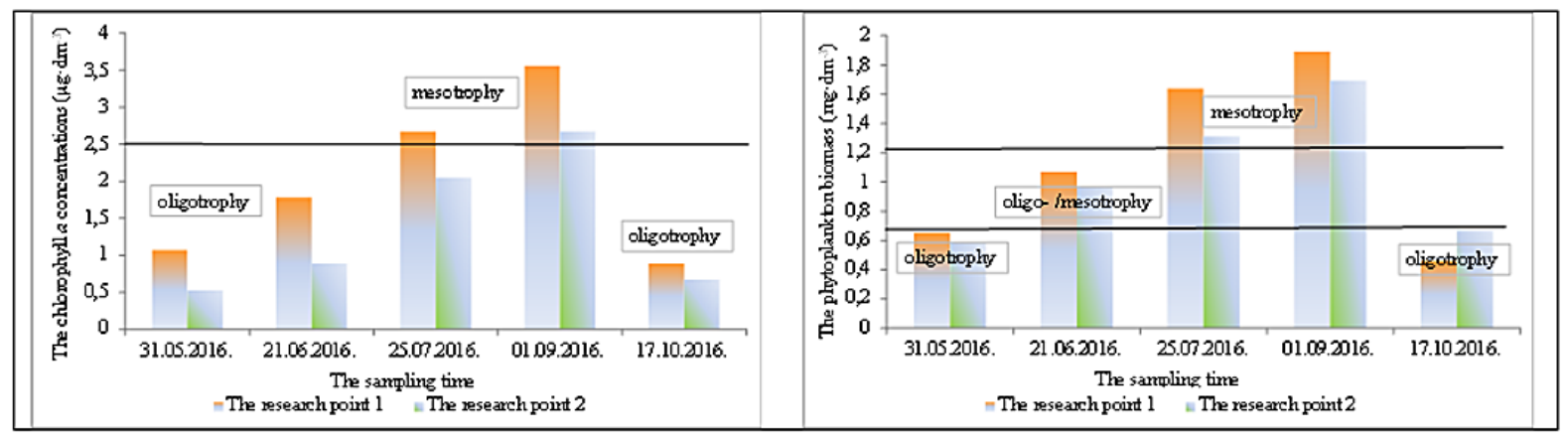

Figure 3. Results of the water trophic level in park ponds

Similar observations were made by Messyasz, Jurgońska [2003] and Salmaso et al. [2017]. The holiday period is also rest time, both for residents of Żywiec and tourists. They visit the Beskids and the park area, which is a very attractive place to rest from the city noise. During this season the greater amount of the biogenic substances probably flowed into the ponds, which are located in this park and also into the Soła River, which feeds these ponds. In addition, it probably caused the increase phytoplankton biomass and chlorophyll $a$ concentrations during this period.

The chemistry of the park ponds is shaped by the river water. Sola flows through areas with disorderly wastewater management, but recently many things are improving (new sewage systems are created and sewage treatment plants are modernized) [Jaguś 2011, 2017]. Despite this, it can affect the periodic increase the pollution of the ponds water. The water of the park ponds was rather clean and had an oligo-mesotrophic character; higher level of the trophy was found only in the summer season. The highest values of phytoplankton biomass and chlorophyll $a$ concentrations were found in September. Similar observations were made in the ponds water of Sołecki Park in Poznań, where the highest concentrations of the chlorophyll $a$ were also found in September [Messyasz, Jurgońska 2003].

The presence of Euglenophyta and Cryptophyta is often observed in the qualitative structure of the planktonic algae, due to the content of the significant organic matter amount and bacteria, which live on this matter and they are food for algae [Wołowski, Kowalska 2009; Dimitrov et al. 2011; Wojciechowska, Lenard 2014; Nishino et al. 2015; Rodrigues et al. 2015]. In turn, the domination of diatoms was observed in these ponds. It can be related to the slight movement of water, due to the feeding of these ponds by the Sola River. The diatoms prefer more turbulent places and water circulation periods, because they have heavy silica shells, which in the stable periods contribute to the sedimentation of the diatoms to the bottom [Kawecka, Eloranta 1994; Wilk-Woźniak, Ligęza 2003; Wang et al. 2018]. The domination of diatoms was also found in the municipal ponds water in Brussels, located along the Vltava River, which are fed by this river (they were flow ponds) [Peretyatko et al. 2007].

The taxa of the diatoms which prefer the oxygenated water with lower fertility were found in the analyzed ponds, including i.a. Achnanthes lanceolata (Brébisson ex Kützing) Grun. in $\mathrm{Cl}$. \& Grun., Encyonema sp. (Kützing) Krammer and Encyonema minutum (Hilse) D.G.Mann [Bubak, Bogaczewicz-Adamczak 2005; Keatley et al. 2009; Falasco et al. 2012].

The presence of Chrysophyta, mainly Dinobryon sp. (Ehrenberg) was found as well. They prefer good oxygenation and low productivity of water [Forsström et al. 2005; Bucka, WilkWoźniak 2007; Ptacnik et al. 2009; Järvinen et al. 
Table 2. The air and water temperature in two research points during the research

\begin{tabular}{|c|c|c|c|c|}
\hline \multirow{2}{*}{ The date } & $\begin{array}{c}\text { The air temperature } \\
\left({ }^{\circ} \mathrm{C}\right)\end{array}$ & $\begin{array}{c}\text { The water temperature } \\
\left({ }^{\circ} \mathrm{C}\right)\end{array}$ & $\begin{array}{c}\text { The air temperature } \\
\left({ }^{\circ} \mathrm{C}\right)\end{array}$ & $\begin{array}{c}\text { The water temperature } \\
\left({ }^{\circ} \mathrm{C}\right)\end{array}$ \\
\hline 31.05 .2016 & \multicolumn{2}{|c|}{ the research point 1 } & 24 & 14 \\
\hline 21.06 .2016 & 25 & 15 & 27 & 17 \\
\hline 25.07 .2016 & 27 & 18 & 34 & 19 \\
\hline 01.09 .2016 & 36 & 19 & 33 & 20 \\
\hline 17.10 .2016 & 33 & 20 & 16 & 13 \\
\hline
\end{tabular}

2013; Wojciechowska, Lenard 2014]. During the research, Cyanobacteriae did not occur, which can confirm a lower trophy level, because they usually indicate the eutrophic conditions [Reynolds 2000; Burchardt, Pawlik-Skowrońska 2005; Rakowska et al. 2005; Ptacnik et al. 2009; Järvinen et al. 2013; Bora et al. 2017; Kozak et al. 2017; Salmaso et al. 2017].

Taxa Pediastrum sp. (Meyen) and Fragilaria crotonensis Kitt. typical for the higher trophy level were recorded only during the summer season [Rakowska et al. 2005; Danielsen 2010; Kozak et al. 2017; Salmaso et al. 2017]. It can confirm the slight water pollution in this season.

The ponds in the Habsburgs Park in Żywiec have a great aesthetic and recreational value; they also increase the diversity of the urban landscape. They are characterized by the richness of the planktonic algae species. Their protection and frequent monitoring are necessary in order to maintain the right trophy level (oligo- and oligo- /mesotrophy), because contaminated ponds water may negatively affect their aesthetics and sanitary conditions. Due to the great recreational importance of the park, should take care of their protection.

\section{REFERENCES}

1. Bora A., Gogoi H.K., Veer V. 2016. Algal Wealth of Northeast India. In: Purkayastha J. (Ed.). Bioprospecting of Indigenous Bioresources of North-East India. Springer Science+Business Media Singapore, 215-228.

2. Bubak I., Bogaczewicz-Adamczak B. 2005. Fossil diatoms and chrysophyceae cysts as indicators of palaeocological changes in Lake Ostrowite (Tuchola Pinewoods). Oceanol. Hydrobiol. St., 34(3), 269-286.

3. Bubíková K., Hrivnák R. 2018. Comparative Macrophyte Diversity of Waterbodies in the Central European landscape. Wetlands, 38, 451-459.

4. Burchardt L., Pawlik-Skowrońska B. 2005.
Blooms of cyanobacteria - interspecies competition and environmental threat. Botanical news, 49(1/2), 39-49. (in Polish).

5. Burchardt L., Messyasz B., Mądrecka B. 2006. Green algae population changes in fish ponds. Teka Kom. Ochr. Kszt. Środ. Przyr., 3, 30-34.

6. Bucka H., Wilk-Woźniak E. 2007. Pro- and eukaryotic algae of phytoplankton communities in reservoirs water in southern Poland. Institute of Freshwater Biology - PAN, Krakow. (in Polish).

7. Chomutowska H., Krzyściak-Kosińska R. 2015. Plankton of selected ponds in the Bialowieza Forest. Ecological Engineering, 42, 1-9. (in Polish).

8. Cox E.J. 1999. Identification of Freshwater Diatoms from Live Material. Chapman and Hall, London.

9. Danielsen R. 2010. Dissimilarities in the recent histories of two lakes in Portugal explained by local-scale environmental processes. J. Paleolimnol., $43,513-534$.

10. Dimitrov. D., Stoyneva M., Ivanov D. 2011. Sofia. In: Kelcey J.G., Müller N. (Eds.). Plants and Habitats of European Cities. Springer Science+Business Media, LLC, 453-475.

11. Dojlido J.R. 1995. Chemistry of surface water. Publishing Company Economics and the Environment, Bialystok. (in Polish).

12. Ejsmont-Karabin J., Kuczyńska-Kippen N. 2001. Urban rotifers: structure and densities of rotifer communities in water bodies of the Poznan agglomeration area (western Poland). Hydrobiologia, 446/447, 165-171.

13. Falasco E., Ector L. Ciaccio E., Hoffmann L., Bona F. 2012. Alpine freshwater ecosystems in a protected area: a source of diatom diversity. Hydrobiologia, 695, 233-251.

14. Fernández C., Estrada V., Parodi E.R. 2015. Factors Triggering Cyanobacteria Dominance and Succession During Blooms in a Hypereutrophic Drinking Water Supply Reservoir. Water Air Soil Poll., 226(73), 1-13.

15. Forsström L., Sorvari S., Korhola A., Rautio M. 2005. Seasonality of phytoplankton in subarctic Lake Saanajärvi in NW Finnish Lapland. Polar Biol., 28, 846-861. 
16. Gąbka M., Dolata P.T. 2010. Rare and endangered communities of the hydrophyte in fish ponds in southern Wielkopolska. Physiographic Research, ser. B - Bot., 01(B59), 075-096. (in Polish).

17. Goswami S.N., Trivedi R.K., Saha S., Mandal A., Jana S. 2017. A study on plankton diversity of three urban ponds in Kolkata of West Bengal State, India. Int. J. Adv. Biol. Research., 7(4), 687-691.

18. Heinonen P. 1980. Quantity and composition of phytoplankton in Finnish inland waters. Nat. Board of Waters., 37, 1-91.

19. Hindák F. 1996. Key to the unbranched filamentous green algae (Ulotrichineae, Ulotrichales, Chlorophyceae). Bul Slov Bot Spol Pri Sav. Suppl., 1, 1-77.

20. Jachniak E., Holubčík M., Ćmiel M., Gazda K. 2015. Evaluation of the water trophic state of Wapienica dam reservoir. Ecological Engineering, 41, 181-187. (in Polish).

21. Jaguś A. 2011. Assessment of trophic state of water in Sola cascade dam reservoirs. Proc. of ECOpole., 5(1), 233-238. (in Polish).

22. Jaguś A. 2017. Soła River dam cascade as a source of tap-water. Acta Geogr. Silesiana, 11/3(27), 2530. (in Polish).

23. Jarvinen M., Drakare S., Free G., Lyche-Solheim A., Phillips G., Skjelbred B., Mischke U., Ott I., Poikane S., Søndergaard M., Pasztaleniec A., Wichelen J.V., Portielje R. 2013. Phytoplankton indicator taxa for reference conditions in Northern and Central European lowland lakes. Hydrobiologia, 704, 97-113.

24. Kawecka B., Eloranta P.V. 1994. Outline of the ecology of the freshwater and terrestrial environments algae. PWN, Warszawa. (in Polish).

25. Keatley B.E., Douglas M.S.V., Blais J.M., Mallory M.L., Smol J.P. 2009. Impacts of seabird-derived nutrients on water quality and diatom assemblages from Cape Vera, Devon Island, Canadian High Arctic. Hydrobiologia, 621, 191-205.

26. Kozak A., Gołdyn R., Dondajewska R., Kowalczewska-Madura K., Holona T. 2017. Changes in phytoplankton and water quality during sustainable restoration of an urban lake used for recreation and water supply. Water, 9(713), 1-16.

27. Ligęza S., Wilk-Woźniak E. 2011. The occurrence of a Euglena pascheri and Lepocinclis ovum bloom in an oxbow lake in southern Poland under extreme environmental conditions. Ecol. Indic., 11, 929-939.

28. Lund J.W.G., Kipling C., Le Gren E.D. 1958. The inverted microscope method of estimating algal numbers and the statistical basis of estimation by counting. Hydrobiologia, 1, 144-170.

29. Messyasz B., Jurgońska M. 2003. Species structure of the phytoplankton in the annual cycle in large and small ponds (Park Sołacki, Poznań). Annals of the Agricultural Academy in Poznan - CCCLIV Bot., 6, 131-145. (in Polish).

30. Miodoński M. 2012. Three days in Żywiec: a guide for a walking tourist. Żywia, Żywiec. (in Polish).

31. Mukhutdinov V.F., Butakova E.A. 2012. Production characteristics of phytoplankton in early years of the existence of Yumaguzin Reservoir. Inland Water Biol., 5(4), 317-321.

32. Nishino H., Hodoki Y., Thottathil S.D., Ohbayashi K., Takao Y., Nakano S. 2015. Identification of species and genotypic compositions of Cryptomonas (Cryptophyceae) populations in the eutrophic Lake Hira, Japan, using single-cell PCR. Aquat. Ecol., 49, 263-272.

33. OECD. 1982. Eutrophication of waters. Monitoring, assessment and control. OECD, Paris.

34. Peretyatko A., Teissier S., Symoens J-J., Triest L. 2007. Phytoplankton biomass and environmental factors over a gradient of clear to turbid peri-urban ponds. Aquat. Conserve. marine and freshwater ecosystems, 17, 584-601.

35. Picińska-Fałtynowicz J., Błachuta J. 2012. The key to identify phytoplankton organisms from rivers and lakes for monitoring purposes of surface water bodies in Poland. Library of Environmental Monitoring, Warszawa. (in Polish).

36. Polish standardization, measurement and quality committee. Polish Standard: Determination of the chlorophyll a concentration by spectrophotometric method. PN-86/C- 5560.02, Warsaw (in Polish).

37. Poviat Eldership in Żywiec. 2013. Strategy for sustainable socio-economic development of the Żywiecki poviat for the years 2006-2020, Update. Poviat Eldership in Żywiec, Żywiec. (in Polish).

38. Ptacnik R., Solimini A., Brettum P. 2009. Performance of a new phytoplankton composition metric along a eutrophication gradient in Nordic lakes. Hydrobiologia, 633, 75-82.

39. Rakowska B., Sitkowska M., Szczepocka E., Szulc B. 2005. Cyanobacteria water blooms associated with various eukaryotic algae in the Sulejow reservoir. Oceanol. Hydrobiol. St., 34(1), 31-38.

40. Reynolds C.S. 2000. Phytoplankton designer-or how to predict compositional responses to trophic - state change. Hydrobiologia, 424, 123-132.

41. Reynolds C.S., Jaworski G.H.M., Roscoe J.V., Hewitt D.P., George D.G. 1998. Responses of the phytoplankton to a deliberate attempt to raise the trophic status of an acidic, oligotrophic mountain lake. Hydrobiologia, 369/370, 127-131.

42. Rodrigues Amaral da Costa M., Attayde J.L., Becker V. 2015. Effects of water level reduction on the dynamics of phytoplankton functional groups 
in tropical semi-arid shallow lakes. Hydrobiologia, 778(1), 75-89.

43. Rott E. 1981. Some results from phytoplankton counting intercalibrations. Schweiz. Z. Hydrol. Birkhäuser Verlag Basel., 43(1), 34-62.

44. Saha S., Saha T., Basu1 P. 2017. Seasonal changes in zooplankton and macro-fauna populations of the East Calcutta Wetland Fish Ponds. Proc. Zool. Soc., 70(2), 156-164.

45. Salmaso N., Boscaini A., Capelli C., Cerasino L. 2017. Ongoing ecological shifts in a large lake are driven by climate change and eutrophication: evidences from a three-decade study in Lake Garda. Hydrobiologia, 824(1), 177-195.

46. Siemińska J. 1964. The freshwater flora of Poland. Bacillariophyceae. PWN, Warszawa. (in Polish).

47. Starmach K. 1989. The phytoplankton of freshwater. The methods of research and keys to identification of species occurring in water of Central Europe. PWN, Warsaw-Krakow. (in Polish).

48. Starmach J., Mazurkiewicz-Boroń G. 2000. Dobczycki reservoir. Ecology - Eutrophication - Protection. Institute of Freshwater Biology - PAN, Krakow. (in Polish).

49. Słomka T., Słomka E. 2007. Geotouristic and tourist attractions of Żywiec. Geotourism, 4(11), 13-22. (in Polish).

50. Szczurowska A. 2003. Flora of peat bogs of the "Międzyrzeki" reserve in the Roztoczański National Park. Acta Agrophysica, 1(3), 569-574. (in Polish).

51. Wang Q., Yang X., Kattel G.R. 2018. Within-lake spatio-temporal dynamics of cladoceran and diatom communities in a deep subtropical mountain lake (Lugu Lake) in southwest China. Hydrobiologia, 820, 91-113.

52. Wilk-Woźniak E. 2003. Phytoplankton - formation reflecting variation of trophy in dam reservoirs. Proc. of the XX th International Phycological Symposium, 24-27 September 2001 (Ecohydrol. and Hydrobiol., 3(2)), 213-219.

53. Wilk-Woźniak E., Ligęza S. 2003. Phytoplankton - nutrient relationships during the early spring and the late autumn in a shallow and polluted reservoir. Oceanol. Hydrobiol. St., 32(1), 75-87.

54. Wilk-Woźniak E., Pociecha A., Ciszewski D., Aleksander- Kwaterczak U., Walusiak, E. 2011. Phyto- and zooplankton in fishponds contaminated with heavy metal runoff from a lead-zinc mine. Oceanol. Hydrobiol. St., 40(4), 77-85.

55. Wojciechowska W., Lenard T. 2014. Effect of extremely severe winters on under-ice phytoplankton development in a mesotrophic lake (Eastern Poland). Oceanol. Hydrobiol. St., 43(2), 147-153.

56. Wołowski K. 2011. Preliminary studies on euglenes and other algae of the Wołosate peatbog in the Bieszczady National Park. Fragmenta Floristica Geobotanica Polonica, 18(1), 131-146. (in Polish).

57. Wołowski K., Kowalska J. 2009. Euglenines and other algae in the flora of the autumn pond in the Botanical Garden of the Jagiellonian University. Fragmenta Floristica et Geobotanica Polonica, 16(1), 145-154. (in Polish).

58. ZhengJian Y., DeFu L., DaoBin J., ShangBin X., YuLing H., Jun M. 2013. An eco-environmental friendly operation: An effective method to mitigate the harmful blooms in the tributary bays of Three Gorges Reservoir. Science China. Technolog Sciences, 56(6), 1458-1470.

59. Żywotko H. 2000. Guide: the trees of the historic Habsburg Park in Żywiec. Publishing House Henryk Żywotko, Żywiec. (in Polish).

60. google.maps. Retrieved 5. 11. 2018, from www. google.maps. 